\title{
Solid-phase synthesis of cyclic peptide chitinase inhibitors: SAR of the argifin scaffold $\dagger$
}

\author{
Mark J. Dixon, ${ }^{a}$ Amit Nathubhai, ${ }^{a}$ Ole A. Andersen, ${ }^{b}$ Daan M. F. van Aalten ${ }^{b}$ and Ian M. Eggleston $* a$ \\ Received 29th August 2008, Accepted 6th October 2008 \\ First published as an Advance Article on the web 13th November 2008 \\ DOI: $10.1039 / \mathbf{b 8 1 5 0 7 7 j}$
}

A new, highly efficient, all-solid-phase synthesis of argifin, a natural product cyclic pentapeptide chitinase inhibitor, is reported. The synthesis features attachment of an orthogonally protected Asp residue to the solid support and assembly of the linear peptide chain by Fmoc SPPS prior to cyclisation and side-chain manipulation on-resin. Introduction of the key $N$-methyl carbamoyl-substituted Arg side chain is achieved via derivatisation of a selectively protected Orn residue, prior to cleavage from the resin and side-chain deprotection. A severe aspartimide side-reaction observed upon final deprotection is circumvented by the use of a novel aqueous acidolysis procedure. The flexibility of the synthesis is demonstrated by the preparation of a series of argifin analogues designed from the X-ray structure of the natural product in complex with a representative family 18 chitinase.

\section{Introduction}

Chitinases catalyse the hydrolysis of chitin (1, Fig. 1), the natural homopolymer of $\beta(1,4)$-linked $N$-acetyl-D-glucosamine. Chitin is a key structural component of the cell walls, exoskeletons, and eggshells of pathogenic fungi, insects, and nematodes, respectively, ${ }^{1}$ which all rely on the ability to hydrolyse chitin at specific points in their life cycles. For this reason, chitinase inhibitors are now attracting considerable interest as novel fungicides ${ }^{2}$ and insecticides, ${ }^{3}$ as well as potential chemotherapeutic agents against a variety of tropical diseases, such as filariases ${ }^{4}$ and malaria. ${ }^{5}$

Although chitin is not found in mammalian physiology, two human chitinases (chitotriosidase $e^{6}$ and acidic mammalian chitinase ${ }^{7}$ ) and several chitin binding proteins (termed chi-lectins ${ }^{8}$ ) have

${ }^{a}$ Wolfson Laboratory of Medicinal Chemistry, Department of Pharmacy and Pharmacology, University of Bath, Claverton Down, Bath, BA2 7AY, UK. E-mail: ie203@bath.ac.uk; Fax: ++4401225386114

${ }^{b}$ Division of Molecular and Environmental Microbiology, University of Dundee, Dundee, DD1 5EH, UK

$\dagger$ Electronic supplementary information (ESI) available: ES-MS data for compounds 10a and 10b. See DOI: 10.1039/b815077j
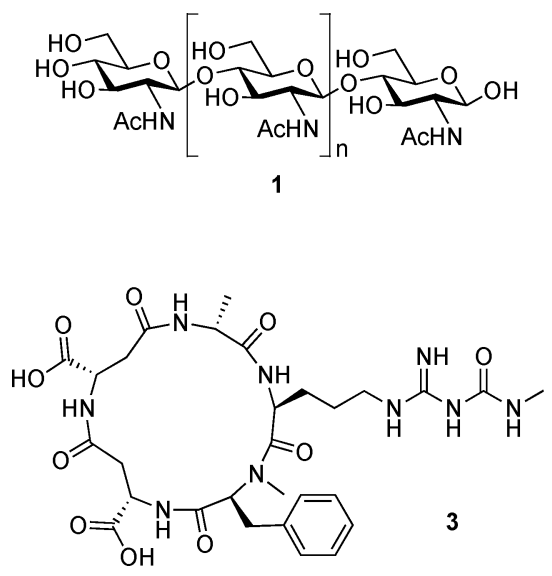

nonetheless been identified. These have been implicated in a number of major disease states including asthma, ${ }^{9}$ osteoarthritis ${ }^{10}$ and lipid storage disease, ${ }^{11}$ and so chitinase inhibitors are therefore also of interest as selective chemical probes to investigate the role of such proteins in these disorders, and as potential drug leads.

So far, most of the chitinase inhibitors that have been identified are either natural products, ${ }^{12}$ or have been inspired by natural product leads. The pseudo-trisaccharide allosamidin $2^{13}$ (Fig. 1), has been widely studied, and is a potent inhibitor of a broad range of family-18 chitinases, as well showing interesting biological effects against fungal and insect pathogens. ${ }^{14,15}$ However, although the total synthesis of $\mathbf{2}$ has been achieved by several laboratories, the complexity of these syntheses limits both its availability and the scope for preparing structural analogues. ${ }^{12,16,17}$

In this context, we have recently focussed our attention on two natural product cyclic pentapeptides, that have been shown to be nanomolar inhibitors of bacterial-type family 18 chitinases. Argifin $3^{18}$ and argadin $\mathbf{4}^{19}$ (Fig. 1), isolated from Gliocladium and Clonostachys fungal cultures respectively, represent a new class of potent chitinase inhibitors that are significantly more synthetically accessible and amenable to rational structure-based optimisation
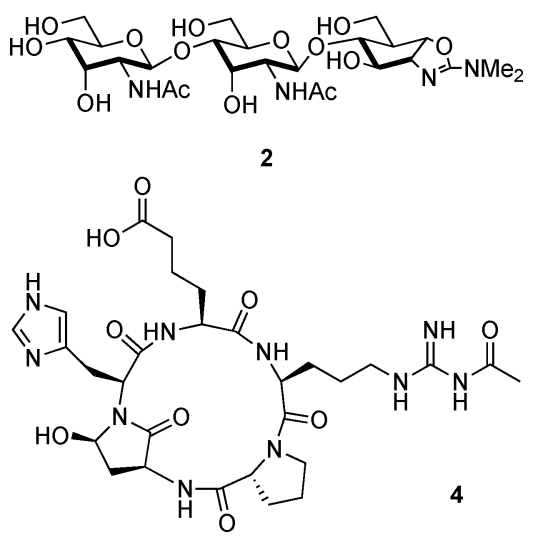

Fig. 1 Chitin 1, allosamidin 2, argifin 3 and argadin 4. 
than allosamidin. The first syntheses of $\mathbf{3}$ and $\mathbf{4}$ were reported by $u s,{ }^{20,21}$ based on a combination of solid-phase and solution techniques.

In our original synthesis of $3{ }^{20}$ the key $N$-methyl carbamoyl modification of the Arg residue was effected in solution as the final step (Scheme 1). However, acidolytic deprotection of the preceding Arg-containing cyclic peptide precursor proved to be problematic, necessitating a time-consuming HPLC purification at this stage of the synthesis and a consequently reduced overall yield. In order to improve the efficiency of production of $\mathbf{3}$, and develop SAR around the argifin scaffold, we have therefore developed a new synthesis of $\mathbf{3}$ and analogues based upon an all-solid-phase approach, in the process identifying a significant side reaction in our previous synthesis, that is eliminated now via a novel side-chain deprotection procedure. The flexibility of the synthetic strategy is demonstrated by the preparation of a series of compounds inspired by the X-ray structure of $\mathbf{3}$ in complex ${ }^{22}$ with a representative family 18 chitinase (chitinase B1 from Aspergillus fumigatus, AfChiB1).

\section{Results and discussion}

\section{Improved solid-phase preparation of argifin}

Our revised approach to argifin is outlined in Scheme 1, path A. In contrast to our original approach (Scheme 1, path B), assembly of the linear peptide chain is now achieved via attachment to the solid-support $\left(\mathrm{P}^{2}\right)$ through the $\alpha$-carboxyl group of an orthogonally protected Asp residue. Instead of releasing the linear precursor into solution, on-resin cyclisation is now effected, after $C$ - and $N$-terminal deprotections $\left(\mathrm{P}^{4}\right.$ and $\left.\mathrm{P}^{5}\right)$. This is followed by introduction of the derivatised Arg side-chain through guanidination of a selectively protected Orn residue $\left(\mathrm{P}^{3}\right)$, before final cleavage from the resin and deprotection of the $\alpha$-carboxyl group of the

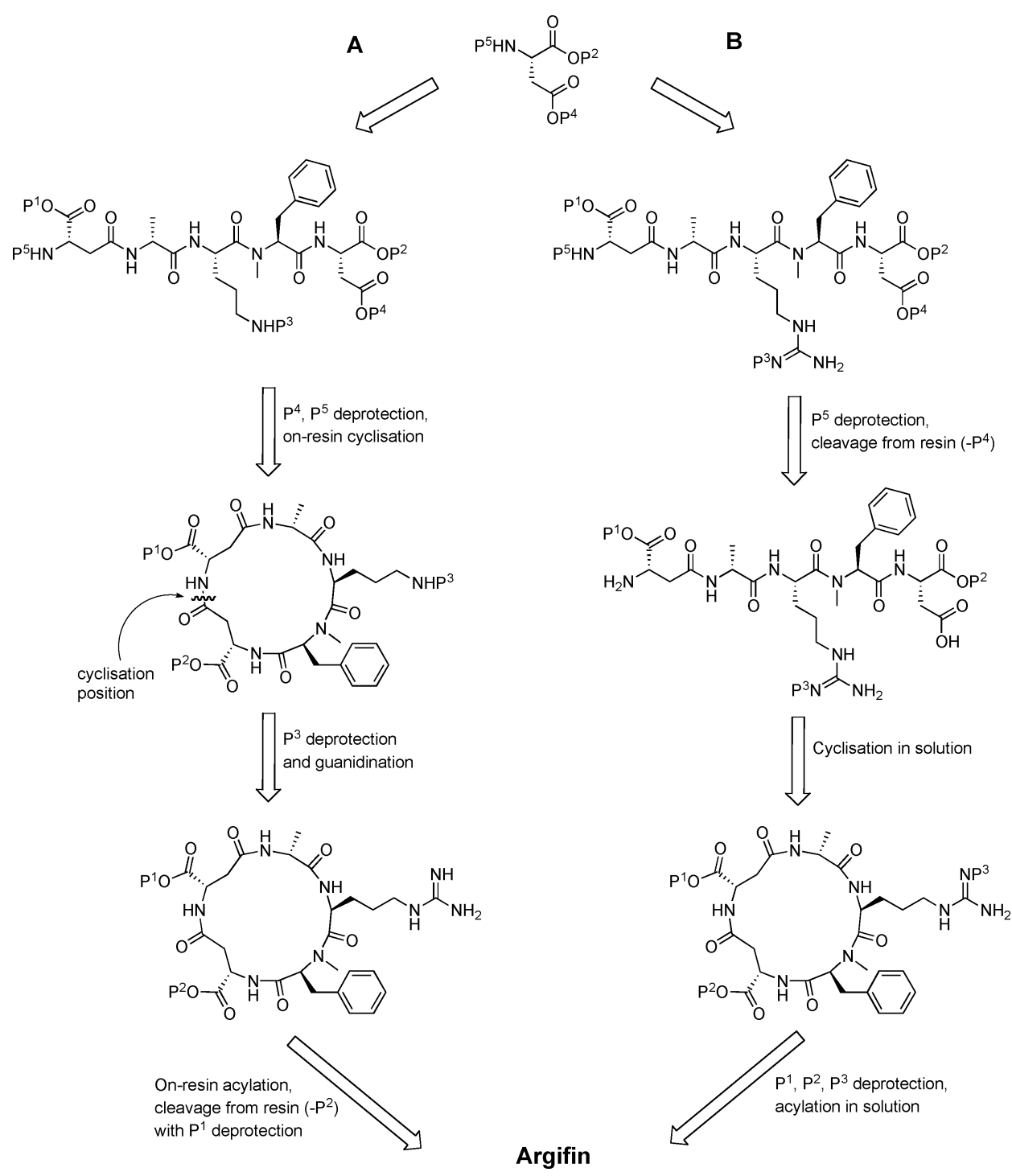

Scheme 1 Synthetic approaches to argifin. Path A: All-solid-phase approach. Path B: Previous combined solid-phase-solution approach. (Path B requires HPLC purification prior to the final acylation stage) ${ }^{20}$ For both synthetic routes, $\mathrm{P}^{5}$ corresponds to temporary $N(\alpha)$-protection. For Path $\mathrm{A}$, $\mathrm{P}^{1}$, $\mathrm{P}^{3}, \mathrm{P}^{4}$ correspond to side-chain protection, $\mathrm{P}^{2}$ to the solid support. For Path $\mathrm{B}, \mathrm{P}^{1}, \mathrm{P}^{2}, \mathrm{P}^{3}$ correspond to side-chain protection, $\mathrm{P}^{4}$ to the solid support. 
second Asp residue $\left(\mathrm{P}^{1}\right)$. Although either of the Asp $\alpha$-carboxyl groups would be a suitable candidate for attachment of the solid support, the residue adjacent to MePhe was initially chosen so as to provide an analogous cyclisation precursor sequence to that employed in solution. Indirect introduction of the Arg residue, via Orn, was envisaged primarily to circumvent use of acid-labile protection for the former, and also to facilitate a fully on-resin approach.

The necessary level of orthogonality between the solid-phase linker and the other protecting groups required was planned as follows. Acid-labile 2-chlorotrityl chloride ${ }^{23}$ polystyrene resin was chosen as solid support $\left(\mathrm{P}^{2}\right)$, with the base-labile Fmoc group as temporary $N^{\alpha}$-protection $\left(\mathrm{P}^{5}\right)$ and $C$-terminal allyl ester protection, removable under neutral conditions, selected for $\mathrm{P}^{4}$. The Dde group, normally cleaved by hydrazinolysis ${ }^{24}$ and stable to both Fmoc and allyl ester deprotection conditions, was chosen to protect the Orn side chain $\left(\mathrm{P}^{3}\right)$, and acid-labile tert-butyl ester protection selected for the $\alpha$-carboxyl group of the second Asp residue $\left(\mathrm{P}^{1}\right)$.
For our synthesis of $\mathbf{3}$ by this approach, Fmoc-Asp-OAll 5 was loaded onto 2-chlorotrityl chloride polystyrene resin to give the orthogonally protected Asp resin $\mathbf{6}$ with a loading of $0.4 \mathrm{mmol} / \mathrm{g}$ (Scheme 2). The desired resin-bound linear peptide 7 was assembled using standard Fmoc SPPS conditions, followed by removal of the $C$-terminal allyl ester $\left(\mathrm{Pd}\left(\mathrm{Ph}_{3} \mathrm{P}\right)_{4} / \mathrm{PhSiH}_{3}\right)^{25}$ and $N$-terminal Fmoc protection to give cyclisation precursor $\mathbf{8}$. Cyclisation was then effected upon the solid support by treatment with PyBOP/DIPEA for $2 \times 2 \mathrm{~h}$. Cleavage of a small sample of resin at this stage with TFA/DCM (1:99) and analysis by HPLC and ES-MS confirmed the success of this transformation, with essentially quantitative conversion to the expected cyclic peptide 10a being observed (Fig. 2a). Surprisingly, when the same material was exposed to a higher concentration of TFA, to effect simultaneous side-chain deprotection (Fig 2b), the product profile was more complex, mirroring the results obtained on attempted deprotection of the Arg side chain of the cyclic peptide in our original synthesis, and with ES-MS analysis also indicating the presence of aspartimide by-products (see ESI $\dagger$ ). That these

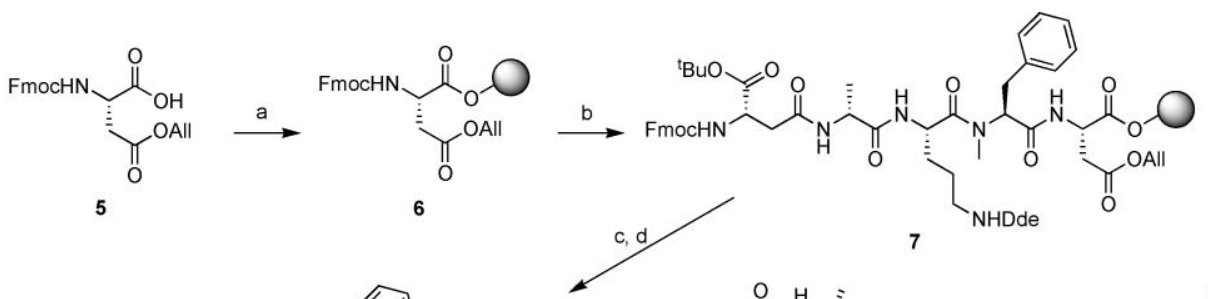

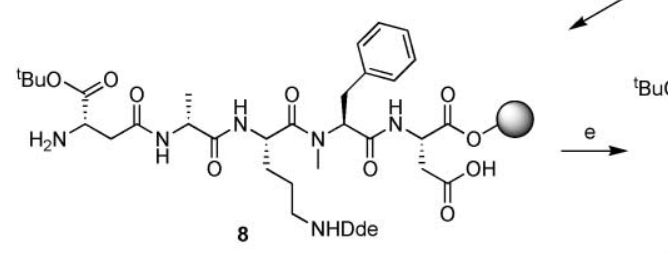<smiles>CNC(=O)C[C@@H](NC(=O)C[C@H](NC=O)C(=O)O)C(=O)O</smiles>

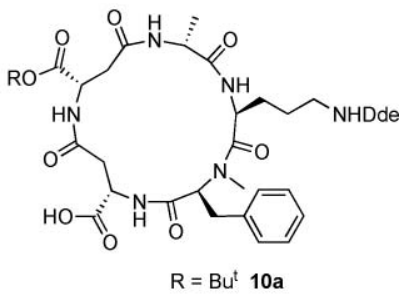

$l^{9}$ $R=H 10 b$

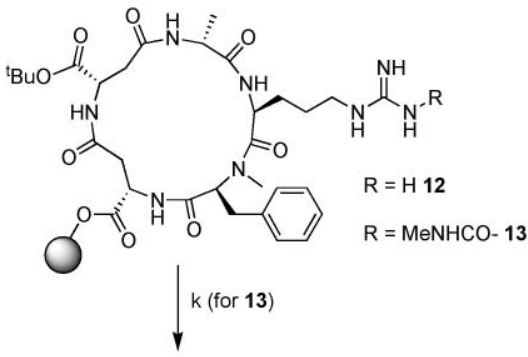

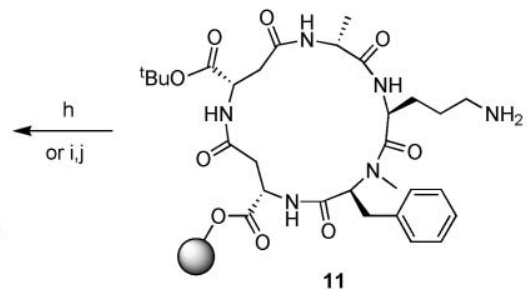

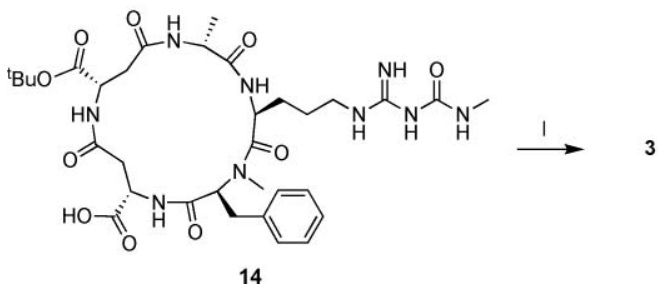

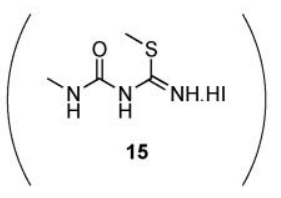

Scheme 2 Reagents and conditions: a) 2-Chlorotrityl chloride polystyrene resin, DIPEA, DCM, 60 min; b) Fmoc $\mathrm{SPPS} ; \mathrm{c}) \mathrm{Pd}\left(\mathrm{Ph}{ }_{3} \mathrm{P}\right)_{4}, \mathrm{PhSiH}_{3}, \mathrm{DCM}$, $3 \times 20 \mathrm{~min}$; d) piperidine/DMF (1:4), $4 \times 3 \mathrm{~min}$; e) PyBOP, DIPEA, DCM, $2 \times 60 \mathrm{~min}$; f) TFA/DCM (1:99), for 10a, TFA/DCM (80:20) for 10b; g) $\mathrm{H}_{2} \mathrm{NNH}_{2}$ /DMF (1:49), $2 \times 15$ min; h) 15, DIPEA, DMF, $2 \times 16$ h; i) $1 H$-pyrazole-1-carboxamidine hydrochloride, DIPEA, DMF, 16 h; j) $N$-succinimidyl $N$-methylcarbamate, DBU, DMF, 2 h; k) TFA/DCM (1:99), $10 \times 2 \mathrm{~min}$; 1$) 1 \mathrm{M} \mathrm{HCl}, 60^{\circ} \mathrm{C}, 90 \mathrm{~min}$. 

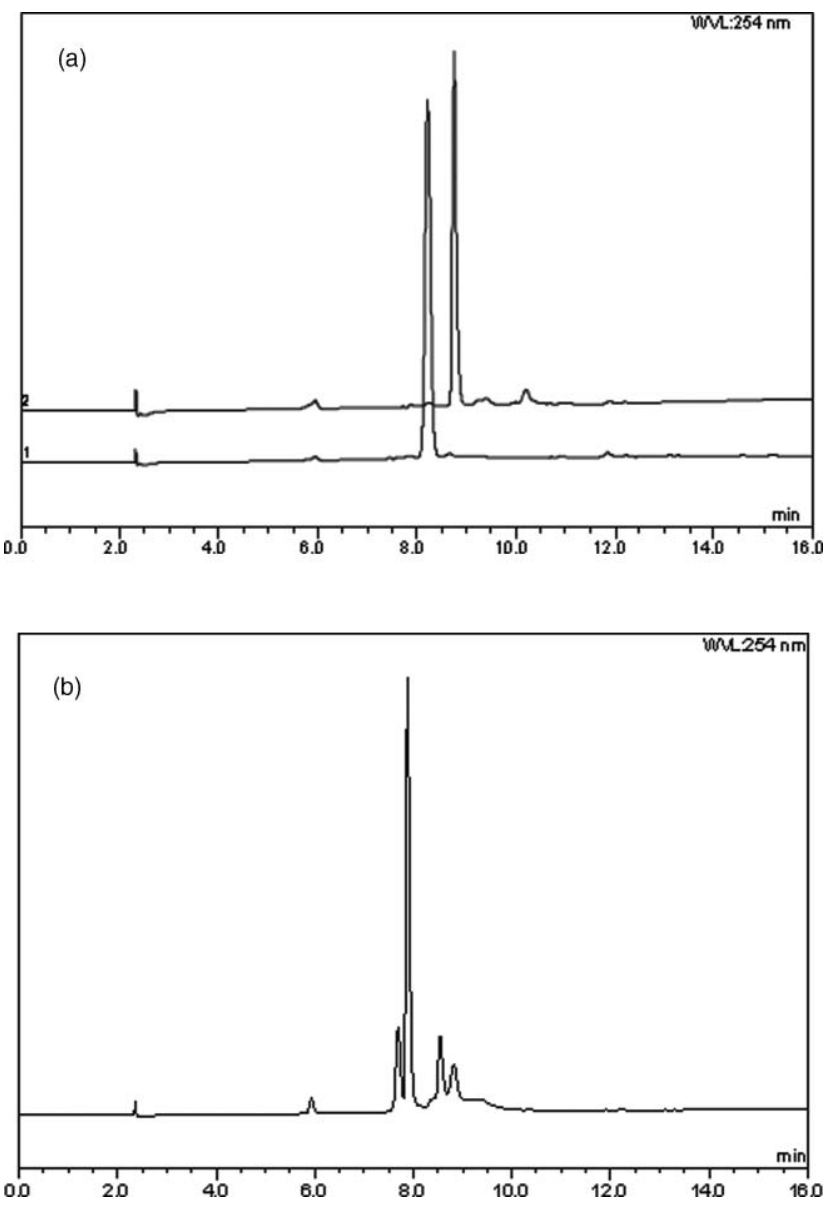

Fig. 2 (a) HPLC of crude cyclisation precursor (lower trace) and crude cyclic peptide 10a (upper trace) following cleavage from the solid support with TFA/DCM (1:99). Conditions: Dionex C-18 column (see experimental), 5-95\% solvent B in $10 \mathrm{~min}$. (b) HPLC of crude cyclic peptide 10b following cleavage from the solid support with TFA/DCM (80:20). Conditions: as for Fig. 2a.

products were generated only upon acidolysis and not by baseinduced aspartimide formation ${ }^{26,27}$ (Scheme 3) during Fmoc synthesis, was confirmed by the observation that cleavage of 7 with $80 \%$ TFA gave rise only to the expected linear pentapeptide in high purity. We had chosen tert-butyl protection for the non-resinlinked Asp residue specifically to eliminate aspartimide formation during linear assembly, based upon our previous observation that the use of $\mathrm{Asp}(\mathrm{OBn})$ was ineffective in this context. ${ }^{20}$ Similarly, elimination of the cyclised product from the solid support, via aspartimide formation during the basic conditions of the final acylation step (see below), was totally suppressed by the use of 2-chlorotrityl resin for the synthesis. ${ }^{28}$

Removal of Dde protection from the resin-bound cyclic pentapeptide 9 was achieved by brief treatment with hydrazine monohydrate in DMF to give $\mathbf{1 1}$ ready for introduction of the derivatised Arg side-chain. The Orn $\rightarrow \operatorname{Arg}(\mathrm{MC})$ transformation was attempted in two ways. Firstly, one-step conversion using the known reagent $15^{29}$ was explored, by analogy with our recently reported synthesis of argadin. However, 15 was found to be rather unreactive and gave only moderate conversion even when used in a large excess and for extended periods (e.g. approx. $15 \%$ conversion with 10 eq. 15, 12 eq. DIPEA in DMF for $2 \times$ $16 \mathrm{~h})$. An alternative, two-step procedure was therefore adopted involving initial guanidination of the Orn residue to Arg, followed by an acylation reaction to insert the $N$-methylcarbamoyl moiety. Thus, treatment of $\mathbf{1 1}$ with 10 eq of $1 H$-pyrazole-1-carboxamidine hydrochloride ${ }^{30}$ for $16 \mathrm{~h}$ gave a quantitative conversion to the Arg derivative 12, which was in turn acylated with $N$-succinimidyl $N$ methylcarbamate in the presence of DBU to give the advanced intermediate 13. Using the same conditions as those applied in the previous solution synthesis, (6 eq. DBU, 3 eq. $N$-succinimidyl $N$-methylcarbamate for $2 \mathrm{~h})^{20} 70 \%$ of the desired mono-acylated compound was obtained, according to HPLC analysis on cleaved material, with only minor amounts of unreacted starting material and the di-acylated product $\mathbf{1 8}$ detectable.

In order to complete the synthesis, it was necessary to cleave the cyclic peptide from the solid support, and remove the remaining tert-butyl ester protection, without aspartimide formation. However, despite considerable experimentation, varying acid concentration and contact time, it was not possible to effect concomitant resin cleavage and side-chain deprotection using TFA/DCM without the formation of some aspartimide products. Indeed, intermediates $\mathbf{1 1}$ and $\mathbf{1 2}$ also proved equally prone to this side reaction upon attempted cleavage.

To overcome this problem, a two-step cleavage/deprotection procedure was ultimately devised. Firstly, the resin-bound cyclic peptide 13 was treated with TFA/DCM (1:99) for $10 \times 2 \mathrm{~min}$ to effect release of the cyclic peptide $\mathbf{1 4}$ only, without sidechain deprotection. As acid-catalysed aspartimide formation upon

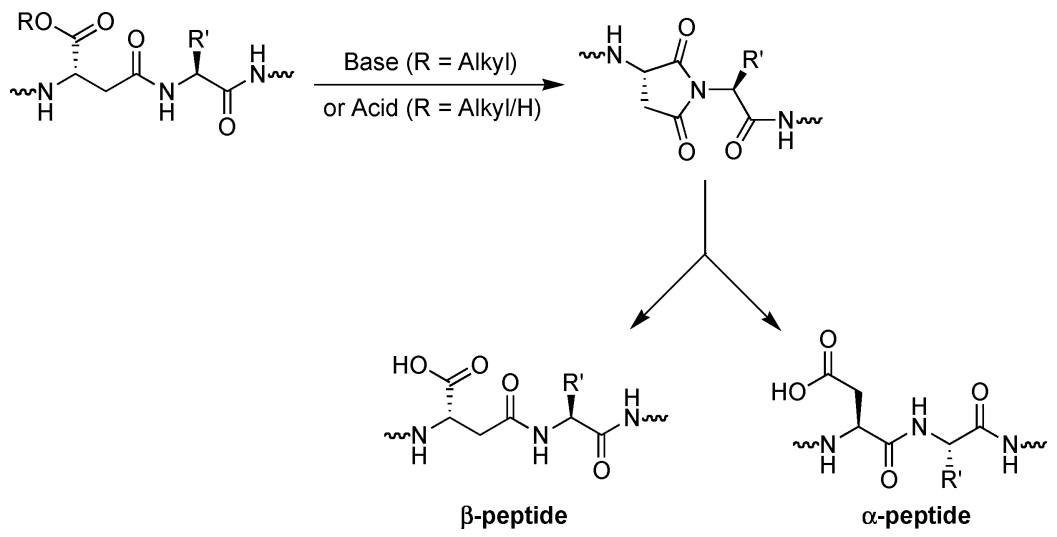

Scheme 3 Formation of aspartimides from $\beta$-peptide derivatives. 
strong acid treatment is known to occur even with unprotected Asp residues,${ }^{31}$ we speculated that in the latter case, aspartimide formation involving the "side-chain" $\alpha$-Asp carboxyls might be avoidable if the tert-butyl ester protection could be effectively cleaved and scavenged first under very mild conditions. The use of aqueous mineral acids has occasionally been proposed as a green alternative to TFA for the removal of tert-butyl protection in peptide synthesis, ${ }^{32}$ as water is known to be an effective scavenger for $\mathrm{Me}_{3} \mathrm{C}^{+}$and other carbenium ion species, ${ }^{33}$ and so to this end 14 was exposed to $1 \mathrm{M}$ aq $\mathrm{HCl}$ at room temperature. Under these conditions, a clean conversion to $\mathbf{3}$ was observed in 5 days, without any detectable aspartimide products. Furthermore, when the reaction was conducted at $60{ }^{\circ} \mathrm{C}$, deprotection was now complete in only 90 min, with no loss in purity (Fig. 3). ${ }^{34}$

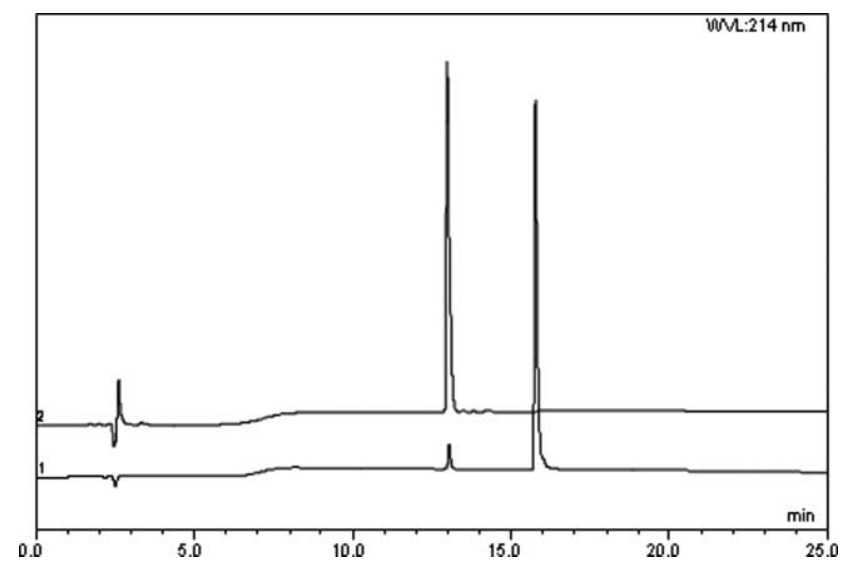

Fig. 3 HPLC of purified tert-butyl ether-protected cyclic peptide 14 (lower trace); following treatment with $1 \mathrm{M} \mathrm{HCl}\left(60^{\circ} \mathrm{C}, 90 \mathrm{~min}\right)$ to generate 3 (upper trace). Conditions: Dionex C-18 column, 5-60\% solvent B in 20 min.

With the incorporation of the two step acidolysis protocol into the synthetic route, 3 was now obtained in $>98 \%$ purity and an overall yield of $18 \%$ over the 17 -step sequence, following a single final HPLC purification (see Figs 4a, b). The isolated product gave ${ }^{1} \mathrm{H}$ and ${ }^{13} \mathrm{C}$ NMR spectra which were identical to those originally reported by Arai et $a l^{18}$ for the natural product, and material previously synthesised by us, confirming that no aspartimide mediated $\beta \rightarrow \alpha$ isomerisation of the Asp linkages had occurred during the second phase of deprotection.

\section{Analogue synthesis}

With an improved synthetic route in hand, a group of argifin analogues were designed (Fig. 5a), based on the high resolution X-ray crystal structure of argifin in complex with $A f$ ChiB1 (Fig. 5b). ${ }^{22}$ The synthesis of the analogues using the newly developed all-solid-phase route generally proceeded smoothly. HPLC and MS analysis at each stage of the syntheses indicated that the critical step was the on-resin cyclisation, which appeared to vary quite significantly in efficiency depending on the analogue in question, and was the main reason for the variation in overall yields observed (Table 1). In particular, the cyclisation reaction was highly sensitive to variations in the $N$-terminal residue of the linear cyclisation precursor $\mathbf{8}$. For example, attempted synthesis of $\mathbf{2 7}$, in which $\beta$ Ala was substituted for $\beta$ Asp at this position,
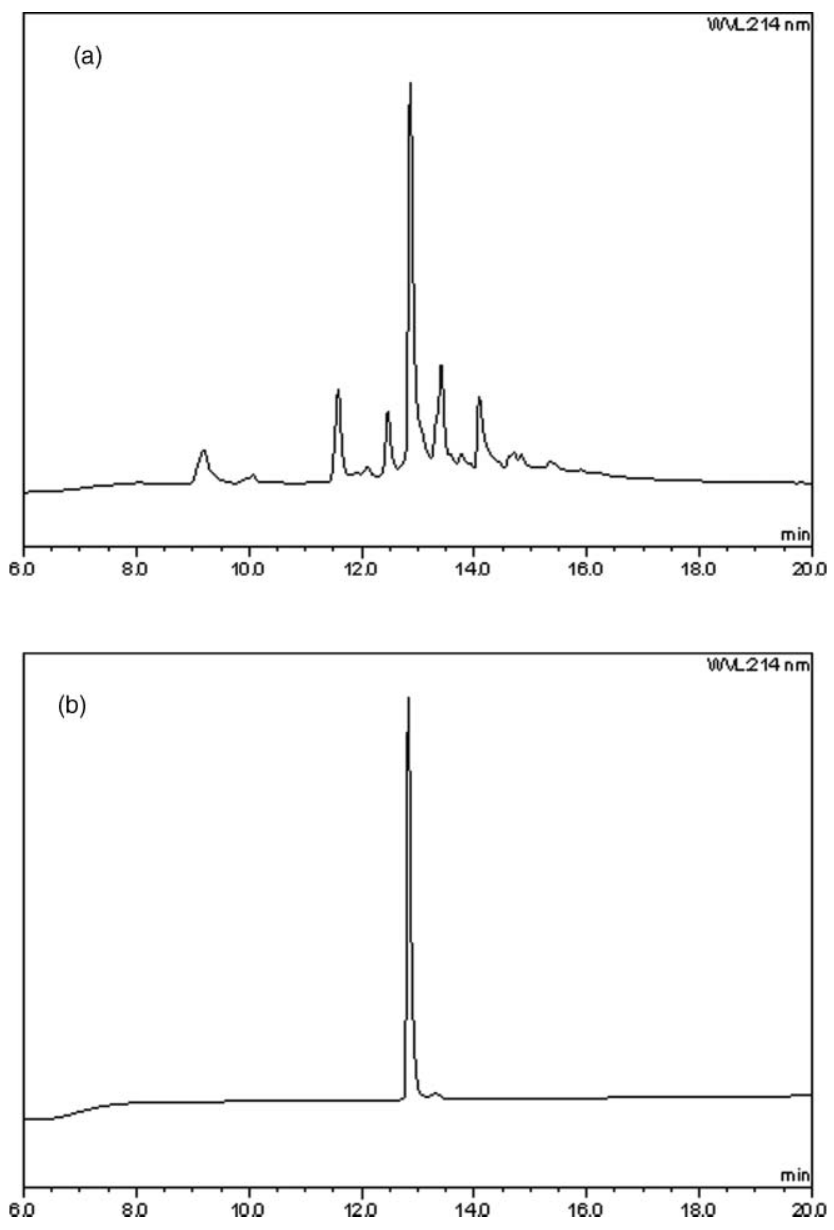

Fig. 4 (a) HPLC of crude argifin 3, following solid-phase assembly and two stage deprotection. Conditions: as for Fig. 3. (b) HPLC of argifin 3, following single final purification. Conditions: as for Fig. 3.

failed completely at the cyclisation step, with no product observed. Similarly, the conservative mutation of the $\mathrm{N}$-terminal $\beta$ Asp to $\beta H s e$ for the synthesis of $\mathbf{2 6}$ had a severe impact, with only minor amounts of cyclised material being detectable upon cleavage. In contrast, when the point of attachment to the solid phase was

Table 1 Details of synthetic yields and enzyme inhibition data for analogues

\begin{tabular}{|c|c|c|c|c|}
\hline Compound & Mutation & $\begin{array}{l}\text { Cyclisation } \\
\text { yield }(\%)^{a}\end{array}$ & $\begin{array}{l}\text { Yield } \\
(\%)^{b}\end{array}$ & $\begin{array}{l}\mathrm{IC}_{50} \\
(\mu \mathrm{M})^{c}\end{array}$ \\
\hline 3 & None & Quant. & 18 & 0.029 \\
\hline 16 & D-Ser for D-Ala & 42 & 2 & 0.280 \\
\hline 17 & D-Thr for D-Ala & 55 & 9 & 0.182 \\
\hline 18 & $\operatorname{Arg}(\mathrm{MC})_{2}$ for $\operatorname{Arg}(\mathrm{MC})$ & $\mathrm{n} / \mathrm{a}$ & $\mathrm{n} / \mathrm{a}$ & 50.0 \\
\hline 19 & $\operatorname{Arg}$ for $\operatorname{Arg}(M C)^{20}$ & $\mathrm{n} / \mathrm{a}$ & $\mathrm{n} / \mathrm{a}$ & $>1000$ \\
\hline 20 & Orn(MC) for $\operatorname{Arg}(M C)$ & 90 & 16 & $>1000$ \\
\hline 21 & His for $\operatorname{Arg}(M C)$ & 34 & 7 & $>1000$ \\
\hline 22 & MeTyr(Bn) for MePhe & 72 & 3 & 0.011 \\
\hline 23 & MeTyr for MePhe & 81 & 10 & 0.144 \\
\hline 24 & Phe for MePhe & 53 & 8 & 60.0 \\
\hline 25 & $\beta$ Hse for $\beta$ Asp & 62 & 11 & 1.200 \\
\hline 26 & $\beta$ Hse for $\beta A s p$ & nd & $\mathrm{n} / \mathrm{a}$ & $\mathrm{n} / \mathrm{a}$ \\
\hline 27 & $\beta$ Ala for $\beta$ Asp & $\mathrm{n} / \mathrm{a}$ & $\mathrm{n} / \mathrm{a}$ & $\mathrm{n} / \mathrm{a}$ \\
\hline
\end{tabular}

${ }^{a}$ From HPLC analysis. ${ }^{b}$ Final isolated yield following HPLC. ${ }^{c}$ Measured against $A f$ ChiB1. 
(a)<smiles>CNC(=O)NC(=N)NCCC[C@H]1NC(=O)[C@H](CO)NC(=O)C[C@@H](C(=O)O)NC(=O)C[C@@H](C(=O)O)NC(=O)[C@@H]2Cc3ccccc3N2C1=O</smiles>

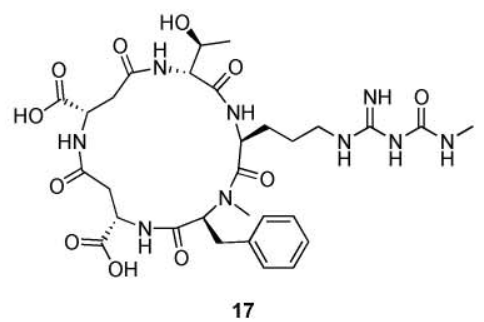

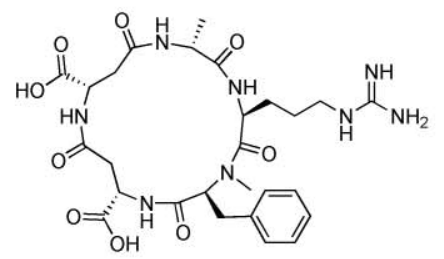

$19^{\mathrm{b}}$

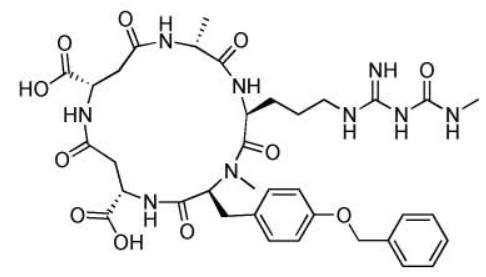

22

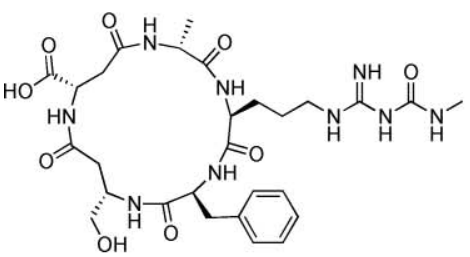

25

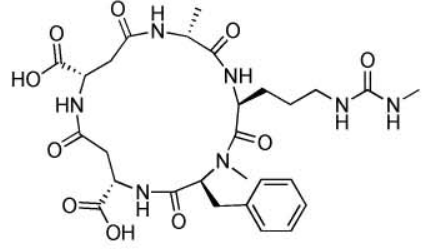

20

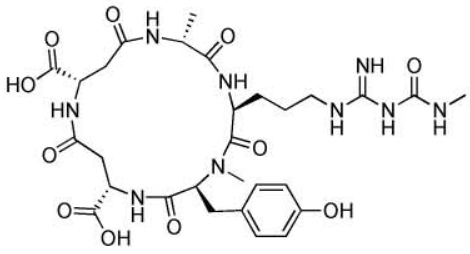

23<smiles>CNC(=O)NC(=N)NCCC[C@@H]1NC(=O)[C@H](C)NC(=O)C[C@@H](CO)NC(=O)C[C@@H](C(=O)O)NC(=O)C2Cc3ccccc3N2C1=O</smiles>

26

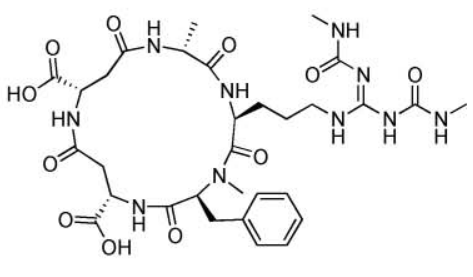

$18^{\mathrm{a}}$<smiles>C[C@H]1NC(=O)C[C@@H](C(=O)O)NC(=O)C[C@@H](C(=O)O)NC(=O)C2Cc3ccccc3CC2N(C)C(=O)[C@H](Cc2cnc[nH]2)NC1=O</smiles>

21<smiles>CNC(=O)NC(=O)NCCC[C@H]1NC(=O)CNC(=O)C[C@@H](C(=O)O)NC(=O)C[C@H](C(=O)O)NC(=O)[C@H](Cc2ccccc2)NC1=O</smiles>

24<smiles>CNC(=O)NC(=N)NCCC[C@H]1NC(=O)CNC(=O)CNC(=O)CC(C(=O)O)NC(=O)Cc2ccccc2N1C</smiles>

27

(b)

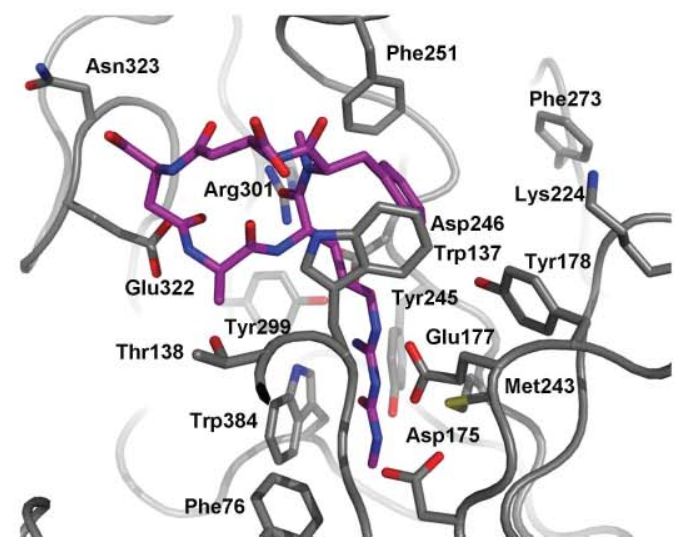

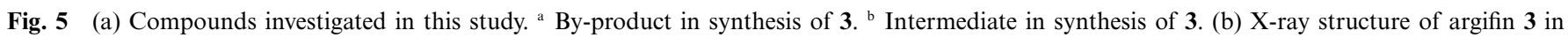
complex with $A f$ ChiB1, showing key residues for SAR development (model extracted from previously published complex ${ }^{22 a}$, PDB entry 1 W9V).

moved to the other Asp residue, in order to allow mutation of the residue adjacent to MePhe in $\mathbf{3}$, an efficient on-resin cyclisation was observed, along with an efficient overall conversion to the desired analogue 25 (Scheme 4).
All the analogues were obtained in pure form after a single HPLC purification, following the two-step resin cleavage and aqueous side-chain deprotection protocol. For the D-Ser, D-Thr and MeTyr analogues 16, 17 and 23 respectively, the tert-butyl 


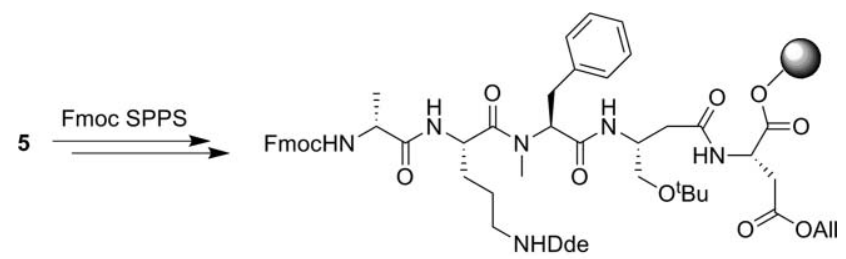

28

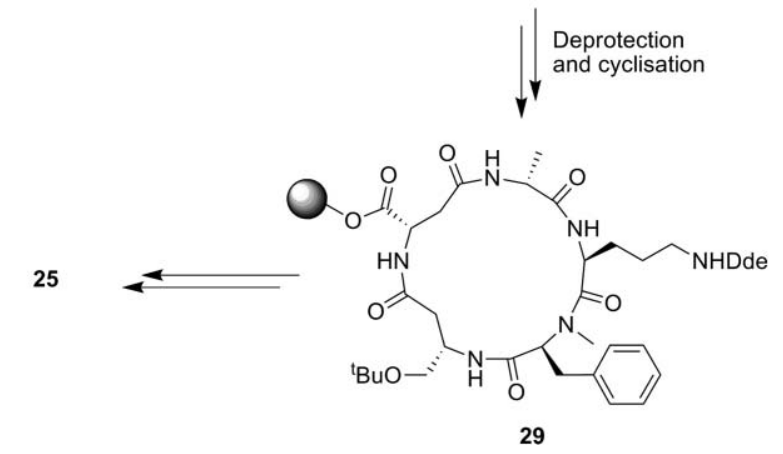

Scheme 4 Synthesis of $\mathbf{2 5}$ via alternative Asp attachment point.

ether side-chain protections used were also smoothly cleaved under the aqueous acidolysis procedure.

\section{Enzymology and SAR studies}

The inhibitory properties of the analogues against $A f \mathrm{ChiB} 1$ were investigated using a fluorometric assay with 4-methylumbelliferyl$\beta-N, N^{\prime}$-diacetylchitobiose as substrate as previously reported. ${ }^{22}$ The $\mathrm{IC}_{50}$ values are shown in Table 1. Substitution in the D-Ala position was fairly well tolerated, with relatively small decreases in potency observed for both $\mathbf{1 6}$ and $\mathbf{1 7}$. This residue appears to form no significant interactions with the protein in the binary $A f \mathrm{ChiB} 1-$ 3 complex. Although it was predicted that introduction of an additional hydroxyl could provide a favourable hydrogen bonding interaction with the nearby Thr138 residue, this was not achieved for either compound. In contrast, replacement of the $\beta$ Asp residue following MePhe with $\beta$ Hse in 25 led to over an order of magnitude increase in $\mathrm{IC}_{50}$. The binary $A f \mathrm{ChiB} 1-\mathbf{3}$ complex reveals a hydrogen bond between the $\alpha$-carboxylate of the Asp residue in question and the indole ring of Trp137. The apparent loss of this interaction through the relatively conservative $\beta$ Asp $\rightarrow \beta$ Hse mutation highlights the importance of this interaction for the binding of argifin-like molecules. Although the same mutation at the other Asp position of the scaffold could not be achieved in this study, it seems likely that it would have a similar impact, since the $\alpha$-carboxyl group of this Asp residue forms three watermediated hydrogen bonds with the carboxyl group of Glu322, and the backbone $\mathrm{N}$ and amide group of Asn323, respectively.

As expected, given the number of binding interactions that are observed involving the $\operatorname{Arg}(\mathrm{MC})$ residue, the argifin scaffold was highly sensitive to modifications at this position. We have indeed recently demonstrated that the methylguanylurea sidechain fragment from the $\operatorname{Arg}(\mathrm{MC})$ residue is the minimum pharmacophore derivable from $3{ }^{22 b}$ Inclusion of a second methyl carbamoyl group in the Arg side chain (18) caused a large decrease in activity, presumably due to steric clashes of the second acyl group with active site residues Asp246, Tyr299 and Trp384, while truncation of $\operatorname{Arg}(\mathrm{MC})$ to $\operatorname{Arg}$ as in 19, or $\operatorname{Orn}(\mathrm{MC})$, i.e. citrulline, in 20, totally abolished activity. The $\operatorname{Arg}(\mathrm{MC}) \rightarrow$ His mutation
21 was inspired by the observation that 4, which interacts with conserved active site residues through this residue, is able to bind deeper into the active site of $A f \mathrm{CHiB} 1$ than $\mathbf{3}$ and forming significantly more interactions, by virtue of its more compact cyclic peptide backbone. ${ }^{22 a}$ However, this substitution once more led to almost total loss of activity, highlighting again the critical role of the $\operatorname{Arg}(\mathrm{MC})$ residue.

Analogues 22-24 designed to probe the role of the MePhe residue also proved highly informative. The binary $A f \mathrm{ChiB} 1-3$ crystal structure reveals the presence of a relatively large pocket, lined by residues 219-220 and 243-247 and the side chains of Tyr178, Lys224 and Phe273, which is situated next to the MePhe benzyl group and occupied by approximately eight ordered water molecules. 22 (MeTyr(Bn) for MePhe) and 23 (MeTyr for MePhe) were designed to expand the inhibitor side chain into this pocket. The extra hydroxyl group of $\mathbf{2 3}$ is potentially favourable by allowing a hydrophilic group to face the ordered water structure of the pocket; however, in the event, the addition of a hydroxyl group did not have any beneficial effect, indicating a possible conflict between this hydrophilic modification and the nearby hydrophobic groups of Trp137 and Phe251, although the reduction in activity is fairly modest, compared to substitutions at $\operatorname{Arg}(\mathrm{MC})$. Extension of the hydrophobic side chain in $\mathbf{2 2}$ did, however, lead as predicted to an increase in potency, presumably due to favourable contacts with residues in the available pocket, lowering the $\mathrm{IC}_{50}$ two-fold relative to 3 itself.

A very significant feature of the $A f \mathrm{ChiB}-\mathbf{3}$ complex, and indeed complexes with other family 18 chitinases, is the presence of a $\beta$-turn centred on the $\operatorname{Arg}(\mathrm{MC})$-MePhe motif, with a cis-amide bond between these residues that occupy respectively the $\mathrm{i}+1$ and $\mathrm{i}+2$ turn positions. This conformation allows the $\operatorname{Arg}(\mathrm{MC})$ side chain to occupy the -1 pocket of the enzyme, whilst providing a favourable orientation of the hydrophobic MePhe side chain. Removal of the $N$-methyl group in compound $\mathbf{2 4}$, led to a 1000 fold drop in activity, suggesting the removal of the preferred cis $\operatorname{Arg}(\mathrm{MC})-\mathrm{MePhe}$ amide bond configuration. To confirm this detail, the conformation of $\mathbf{2 4}$ was studied in detail, both in solution and bound to the enzyme. ROSEY NMR experiments in $\mathrm{D}_{2} \mathrm{O}$ revealed an absence of correlations between the $\alpha$-protons of the Arg and Phe residues, or between the Arg $\beta$ methylene protons and the Phe aromatic protons, thus confirming the predominantly trans-configuration of the Arg-Phe amide bond in $\mathbf{2 4}$ in solution. It should be noted that $\mathbf{3}$ and also all the analogues prepared (apart from 21) do show these diagnostic features, as well as an Arg $\beta$-methylene proton appearing at unusually low field in the $1 \mathrm{D}$ spectrum $\left(\delta_{\mathrm{H}}=-0.43 \mathrm{ppm}\right.$ for 3 ), which is significantly shifted $\left(\delta_{\mathrm{H}}=1.52 \mathrm{ppm}\right)$ in $\mathbf{2 4}$. To probe the configuration of this amide bond when bound to the enzyme, a complex of $\mathbf{2 4}$ and AfChiB1 was obtained by soaking, and the resulting high-resolution (1.9 ̊) X-ray crystal structure investigated (data not shown). This revealed that $\mathbf{2 4}$ does in fact bind with the key amide bond in question still adopting the cis-configuration. The poor affinity of 24 must therefore result from the necessity of an unfavourable trans-to-cis isomerisation occurring prior to binding.

\section{Conclusions}

We have devised an efficient all-solid-phase route to the potent chitinase inhibitor argifin. All the steps proceed with high 
efficiency, which should therefore allow the approach to be adapted to automation and scale-up. The formation of aspartimide products upon TFA-based cleavage of side-chain protecting groups is avoided by indirect introduction of the Arg residue, and the use of aqueous acidolysis to achieve final removal of tert-butyl protection. Argifin analogues obtained by this protocol provide valuable SAR concerning the cyclic peptide scaffold, and in particular highlight the key role played by the $\operatorname{Arg}(\mathrm{MC})-\mathrm{MePhe}$ dipeptide in binding. Further studies are ongoing to apply these lessons to the design of potent peptidomimetic inhibitors.

\section{Experimental}

\section{General information}

NMR spectra were acquired on a Varian Mercury VX400 MHz spectrometer, operating at $400 \mathrm{MHz}$ for ${ }^{1} \mathrm{H}$ and $100 \mathrm{MHz}$ for ${ }^{13} \mathrm{C}$, or a Varian Unity INOVA $600 \mathrm{MHz}$ spectrometer, operating at $600 \mathrm{MHz}$ for ${ }^{1} \mathrm{H}$ and $150 \mathrm{MHz}$ for ${ }^{13} \mathrm{C}$. All coupling constants ( $J$ values) were measured in Hertz. High resolution mass spectrometry was performed using a Bruker MicroTOF autospec electrospray ionisation mass spectrometer. Analytical RP-HPLC was performed on a Dionex HPLC system equipped with a Dionex Acclaim $3 \mu \mathrm{m} \mathrm{C}-18(150 \times 4.6 \mathrm{~mm})$ column with a flow rate of $1 \mathrm{~mL} / \mathrm{min}$. Preparative RP-HPLC was performed on a Dionex HPLC system equipped with a Phenomenex Gemini $5 \mu \mathrm{m} \mathrm{C-18}$ $(250 \times 30 \mathrm{~mm})$ column with a flow rate of $22.5 \mathrm{~mL} / \mathrm{min}$. Mobile phase A was $0.1 \%$ TFA in water, Mobile phase B was $0.1 \%$ TFA in acetonitrile.

\section{Synthesis of argifin 3 and analogues 16-18 and 20-25}

Resin loading: 2-Chlorotrityl chloride polystyrene resin (1.2 mmol/g loading) was treated with Fmoc-Asp(OAll)-OH (1 eq) and DIPEA (4 eq) in DCM for $60 \mathrm{~min}$. The resin was filtered and treated with DCM/MeOH/DIPEA (17:2:1) for $15 \mathrm{~min}$, drained, and washed sequentially with DMF, DCM, MeOH, and $\mathrm{Et}_{2} \mathrm{O}$ (5× each). Resin loading was measured after the first Fmoc deprotection step using the Fmoc method. Fmoc deprotection: The resin was swollen in DCM for $20 \mathrm{~min}$, drained and treated with piperidine/DMF (1:4 v/v, $3 \mathrm{~mL})$ for $3 \mathrm{~min}$. The resin was drained and the procedure repeated a further 3 times. The resin was drained and washed sequentially with DMF, DCM, MeOH and $\mathrm{Et}_{2} \mathrm{O}(5 \times$ each). Peptide couplings: The resin was swollen in DCM for $20 \mathrm{~min}$, drained and treated with a solution of Fmoc-amino acid (2 eq), PyBOP (1.9 eq), and DIPEA (4 eq) in DCM/DMF (v/v 4:1) for $60 \mathrm{~min}$, except in the case of coupling to MePhe where $\mathrm{PyBrOP}^{35}$ (2 eq) was used. The resin was drained and washed with DMF, DCM, $\mathrm{MeOH}$, and $\mathrm{Et}_{2} \mathrm{O}$ ( $5 \times$ each). Solid phase reactions were monitored by the qualitative Kaiser test for the detection of primary amines and the chloranil test for detection of secondary amines. Allyl ester cleavage: The resin was swollen in degassed DCM for $20 \mathrm{~min}$, drained, and treated with $\mathrm{DCM} / \mathrm{PhSiH}_{3}$ (v/v $3: 1)$ for $2 \mathrm{~min}$, prior to the addition of $\mathrm{Pd}\left(\mathrm{Ph}_{3} \mathrm{P}\right)_{4}(20 \mathrm{mg})$. After $20 \mathrm{~min}$ reaction, the resin was drained and washed with dry DCM (10×). The procedure was repeated twice, then the resin was drained and washed sequentially with DMF, DCM, MeOH and $\mathrm{Et}_{2} \mathrm{O}(5 \times$ each $)$. Peptide backbone cyclisation: The resin was swollen in DCM for $20 \mathrm{~min}$, drained, and treated with a solution of PyBOP
( 2 eq) and DIPEA ( 4 eq) in DCM for $2 \mathrm{~h}$. The resin was drained and the procedure repeated. The resin was then drained and washed sequentially with DMF, DCM, MeOH and $\mathrm{Et}_{2} \mathrm{O}$ (5× each). Dde deprotection: The resin was swollen in DCM for $20 \mathrm{~min}$, drained and treated with a solution of hydrazine monohydrate/DMF (v/v 1:49) for $15 \mathrm{~min}$. The resin was drained and the procedure repeated. The resin was then drained and washed sequentially with DMF, $\mathrm{DCM}, \mathrm{MeOH}$ and $\mathrm{Et}_{2} \mathrm{O}(5 \times$ each). Guanidination: The resin was swollen in DCM for 20 min, drained and treated with a solution of $1 H$-pyrazole-1-carboxamidine hydrochloride (10 eq) and DIPEA (12 eq) in DMF for $16 \mathrm{~h}$. The resin was drained into $1 \mathrm{M}$ aqueous $\mathrm{CuSO}_{4}$ and washed sequentially with DMF, DCM, MeOH and $\mathrm{Et}_{2} \mathrm{O}(5 \times$ each). The whole procedure was then repeated. Acylation: The resin was swollen in DCM for $20 \mathrm{~min}$, drained and treated with a solution of $N$-succinimidyl- $N$-methylcarbamate (3 eq) and DBU (6 eq) in DMF for $2 \mathrm{~h}$. The resin was drained and washed sequentially with DMF, DCM, MeOH and $\mathrm{Et}_{2} \mathrm{O}(5 \times$ each). The whole procedure was then repeated. Cleavage from the resin: The resin was swollen in DCM for $20 \mathrm{~min}$, drained and treated with TFA/DCM (1:99) for $2 \mathrm{~min}$. The resin was drained into a solution of pyridine/ $\mathrm{MeOH}(\mathrm{v} / \mathrm{v} 1: 9)$ and the procedure repeated a further 9 times. The combined filtrates were evaporated to dryness to give the partially protected cyclic peptides. Aqueous side-chain acidolysis: The crude cyclic peptides were dissolved in $1 \mathrm{M}$ aq $\mathrm{HCl}(1.5 \mathrm{mg} / \mathrm{mL})$ and heated at $60{ }^{\circ} \mathrm{C}$ for $90 \mathrm{~min}$. Evaporation of the solvent, followed by purification by preparative HPLC and lyophilisation gave the final deprotected peptides as TFA salts in $>95 \%$ purity.

\section{Argifin (3)}

Scale: $0.094 \mathrm{mmol}$. Yield: $13.0 \mathrm{mg}, 18 \% .{ }^{1} \mathrm{H}$ NMR $(600 \mathrm{MHz}$, $\left.\mathrm{D}_{2} \mathrm{O}\right): \delta 7.26-7.10(5 \mathrm{H}, \mathrm{m}$, MePhe $2 \times \delta \mathrm{CH}, 2 \times \varepsilon \mathrm{CH}, \zeta \mathrm{CH})$, $5.01(1 \mathrm{H}, \mathrm{dd}, J=12,3$, MePhe $\alpha \mathrm{CH}), 4.66(1 \mathrm{H}, \mathrm{m}, \mathrm{Asp} \alpha \mathrm{CH})$, $4.42(1 \mathrm{H}, \mathrm{dd}, J=12,2.5, \operatorname{Asp} \alpha \mathrm{CH}), 4.18(1 \mathrm{H}, \mathrm{m}, \operatorname{Arg} \alpha \mathrm{CH})$, $4.06(1 \mathrm{H}, \mathrm{q}, J=7$, Ala $\alpha \mathrm{CH}), 3.08-2.84\left(6 \mathrm{H}, \mathrm{m}, \mathrm{MePhe} \mathrm{\beta CH}_{2}\right.$, $\left.\operatorname{Arg} \mathrm{CCH}_{2}, \operatorname{Asp~} \mathrm{BCH}_{2}\right), 2.76\left(3 \mathrm{H}, \mathrm{s}, \mathrm{MePhe} \mathrm{NCH}_{3}\right), 2.67(1 \mathrm{H}, \mathrm{m}$, Asp $\beta \mathrm{CH} H), 2.63(3 \mathrm{H}, \mathrm{s}, \mathrm{MeCbm} \mathrm{CH}), 2.39(1 \mathrm{H}, \mathrm{t}, J=13$, Asp $\beta \mathrm{CH} H), 1.29(1 \mathrm{H}, \mathrm{m}, \operatorname{Arg} \gamma \mathrm{CH} H), 1.19\left(3 \mathrm{H}, \mathrm{d}, J=7\right.$, Ala $\left.\beta \mathrm{CH}_{3}\right)$, 1.10-0.94 (2H, m, Arg $\gamma \mathrm{CH} H, \operatorname{Arg} \beta \mathrm{CH} H),-0.44(1 \mathrm{H}, \mathrm{m}, \operatorname{Arg}$ $\beta \mathrm{CH} H) ;{ }^{13} \mathrm{C}$ NMR $\left(100 \mathrm{MHz}, \mathrm{D}_{2} \mathrm{O}\right): \delta 175.3,174.3,171.5,171.4$, 170.3, 155.2, 137.5, 129.7, 129.2, 127.3, 62.3, 50.6, 50.0, 49.6, 48.8, 40.7, 37.8, 35.1, 33.4, 29.9, 26.6, 26.1, 24.0, 16.8; Analytical RPHPLC (5-60\% B in $20 \mathrm{~min}, \lambda=220 \mathrm{~nm}): \mathrm{R}_{\mathrm{t}}: 13.0 \mathrm{~min}$; MS (ES+) calcd for $\mathrm{C}_{29} \mathrm{H}_{42} \mathrm{~N}_{9} \mathrm{O}_{10}$ : 676.3055; found: $676.3018[\mathrm{M}+\mathrm{H}]^{+}$.

\section{D-Ala $\rightarrow$ D-Ser (16)}

Scale: 0.094 mmol. Yield: $1.8 \mathrm{mg}, 2 \%{ }^{1} \mathrm{H}$ NMR (600 MHz, $\left.\mathrm{D}_{2} \mathrm{O}\right)$ : $\delta$ 7.32-7.16 (5H, m, MePhe $2 \times \delta \mathrm{CH}, 2 \times \varepsilon \mathrm{CH}, \zeta \mathrm{CH}), 5.08$ $(1 \mathrm{H}, \mathrm{dd}, J=11.5,3$, MePhe $\alpha \mathrm{CH}), 4.69(1 \mathrm{H}, \mathrm{m}$, Asp $\alpha \mathrm{CH})$, $4.47(1 \mathrm{H}, \mathrm{dd}, J=11.5,2.5$, Asp $\alpha \mathrm{CH}), 4.28-4.22$ (2H, m, Arg $\alpha \mathrm{CH}$, Ser $\alpha \mathrm{CH}), 3.71\left(2 \mathrm{H}, \mathrm{d}, J=5.5\right.$, Ser $\left.\beta \mathrm{CH}_{2}\right), 3.11(1 \mathrm{H}, \mathrm{m}$, MePhe $\beta \mathrm{CH} H$ ), 3.02-2.92 (4H, m, MePhe $\beta \mathrm{CH} H$, Arg $\delta \mathrm{CH}_{2}$,

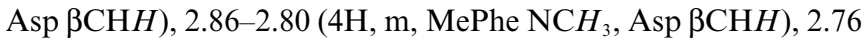
$(1 \mathrm{H}, \mathrm{m}, \mathrm{Asp} \beta \mathrm{CH} H), 2.69\left(3 \mathrm{H}, \mathrm{s}, \mathrm{MeCbm} \mathrm{CH}_{3}\right), 2.53(1 \mathrm{H}, \mathrm{t}, J=$ 13, Asp $\beta \mathrm{CH} H), 1.35(1 \mathrm{H}, \mathrm{m}, \operatorname{Arg} \gamma \mathrm{CH} H), 1.14-1.03(2 \mathrm{H}, \mathrm{m}$, $\operatorname{Arg} \gamma \mathrm{CH} H, \operatorname{Arg} \beta \mathrm{CH} H),-0.34(1 \mathrm{H}, \mathrm{m}, \operatorname{Arg} \beta \mathrm{CH} H) ;{ }^{13} \mathrm{C} \mathrm{NMR}$ (100 MHz, $\left.\mathrm{D}_{2} \mathrm{O}\right): \delta 175.5,174.4,172.1,171.7,171.4,170.5,137.5$, 
$129.7,129.2,127.3,62.3,61.3,55.6,50.6,50.2,48.9,40.7,38.0$, 35.1, 33.3, 29.9, 26.6, 26.1, 24.0; Analytical RP-HPLC (5-60\% $\mathrm{B}$ in $20 \mathrm{~min}, \lambda=220 \mathrm{~nm}$ ): $\mathrm{R}_{\mathrm{t}}: 12.5 \mathrm{~min}$; $\mathrm{MS}(\mathrm{ES}+)$ calcd for $\mathrm{C}_{29} \mathrm{H}_{42} \mathrm{~N}_{9} \mathrm{O}_{11}$ : 692.2998; found: $692.2967[\mathrm{M}+\mathrm{H}]^{+}$.

\section{D-Ala $\rightarrow$ D-Thr (17)}

Scale: $0.107 \mathrm{mmol}$. Yield: $7.7 \mathrm{mg}, 9 \% .{ }^{1} \mathrm{H}$ NMR (400 MHz, $\left.\mathrm{D}_{2} \mathrm{O}\right)$ : 6 7.28-7.12 (5H, m, MePhe $2 \times \delta \mathrm{CH}, 2 \times \varepsilon \mathrm{CH}, \zeta \mathrm{CH}), 5.06(1 \mathrm{H}, \mathrm{dd}$, $J=11,3$, MePhe $\alpha \mathrm{CH}), 4.63(1 \mathrm{H}, \mathrm{dd}, J=13,3$, Asp $\alpha \mathrm{CH}), 4.45$ $(1 \mathrm{H}, \mathrm{dd}, J=11.5,2.5$, Asp $\alpha \mathrm{CH}), 4.23(1 \mathrm{H}, \mathrm{m}, \mathrm{Arg} \alpha \mathrm{CH}), 4.03-$ $3.92(2 \mathrm{H}, \mathrm{m}$, Thr $\alpha \mathrm{CH}$, Thr $\beta \mathrm{CH}), 3.06(1 \mathrm{H}, \mathrm{m}, \mathrm{MePhe} \beta \mathrm{CH} H)$, 3.00-2.81 (4H, m, MePhe $\beta \mathrm{CH} H, \operatorname{Arg} \delta \mathrm{CH}_{2}$, Asp $\left.\beta_{\mathrm{CH}} \mathrm{H}_{2}\right), 2.77$ $\left(3 \mathrm{H}, \mathrm{s}, \mathrm{MePhe} \mathrm{NCH}_{3}\right), 2.75-2.67(2 \mathrm{H}, \mathrm{m}, 2 \times \mathrm{Asp} \beta \mathrm{CH} H), 2.65$ $\left(3 \mathrm{H}, \mathrm{s}, \mathrm{MeCbm} \mathrm{CH} \mathrm{H}_{3}\right), 2.54(1 \mathrm{H}, \mathrm{t}, J=13, \mathrm{Asp} \beta \mathrm{CH} H), 1.31(1 \mathrm{H}$, $\mathrm{m}, \operatorname{Arg} \gamma \mathrm{CH} H), 1.09-0.98$ (5H, m, Arg $\gamma \mathrm{CH} H$, Thr $\gamma \mathrm{CH}_{3}$, Arg $\beta \mathrm{CH} H),-0.43(1 \mathrm{H}, \mathrm{m}, \operatorname{Arg} \beta \mathrm{CH} H) ;{ }^{13} \mathrm{C} \mathrm{NMR}\left(100 \mathrm{MHz}, \mathrm{D}_{2} \mathrm{O}\right): \delta$ 175.2, 174.3, 174.2, 172.2, 171.8, 171.4, 170.5, 137.5, 129.7, 129.2, 127.3, 67.4, 62.3, 59.6, 50.4, 50.1, 48.9, 40.7, 37.9, 35.1, 33.3, 29.9, 26.6, 26.1, 24.2, 19.2; Analytical RP-HPLC (5-60\% B in $20 \mathrm{~min}$, $\lambda=220 \mathrm{~nm}$ ): $\mathrm{R}_{\mathrm{t}}: 12.7 \mathrm{~min}$; $\mathrm{MS}(\mathrm{ES}+)$ calcd for $\mathrm{C}_{30} \mathrm{H}_{44} \mathrm{~N}_{9} \mathrm{O}_{11}$ : 706.3155; found: $706.3149[\mathrm{M}+\mathrm{H}]^{+}$.

\section{$\operatorname{Arg}(\mathrm{MC}) \rightarrow \operatorname{Arg}(\mathrm{MC})_{2}(18)$ - minor diacylated product from argifin synthesis}

${ }^{1} \mathrm{H}$ NMR (600 MHz, D $\left.\mathrm{O}\right): \delta 7.26-7.11(5 \mathrm{H}, \mathrm{m}$, MePhe $2 \times \delta \mathrm{CH}$, $2 \times \varepsilon \mathrm{CH}, \zeta \mathrm{CH}), 5.02(1 \mathrm{H}, \mathrm{m}, \mathrm{MePhe} \alpha \mathrm{CH}), 4.55(1 \mathrm{H}, \mathrm{m}, \mathrm{Asp}$ $\alpha \mathrm{CH}), 4.34(1 \mathrm{H}, \mathrm{dd}, J=12,2, \mathrm{Asp} \alpha \mathrm{CH}), 4.23(1 \mathrm{H}, \mathrm{m}, \mathrm{Arg}$ $\alpha \mathrm{CH}), 4.05(1 \mathrm{H}, \mathrm{q}, J=7$, Ala $\alpha \mathrm{CH}), 3.13-3.02$ (4H, m, MePhe $\beta \mathrm{CH} H, \mathrm{MeCbm} \mathrm{CH}_{3}$ ), 2.97-2.87 (4H, m, MePhe $\beta \mathrm{CH} H$, Arg $\delta \mathrm{CH}_{2}$, Asp $\left.\beta \mathrm{CH} H\right), 2.76-2.62\left(8 \mathrm{H}, \mathrm{m}, \mathrm{MePhe} \mathrm{NCH}_{3}, \mathrm{MeCbm}\right.$ $\left.\mathrm{CH}_{3}, 2 \times \operatorname{Asp~} \beta \mathrm{CH} H\right), 2.35(1 \mathrm{H}, \mathrm{t}, J=13$, Asp $\beta \mathrm{CH} H), 1.34$ $(1 \mathrm{H}, \mathrm{m}, \operatorname{Arg} \gamma \mathrm{CH} H), 1.20\left(3 \mathrm{H}, \mathrm{d}, J=7\right.$, Ala $\left.\beta \mathrm{CH}_{3}\right), 1.13(1 \mathrm{H}$, $\mathrm{m}, \operatorname{Arg} \gamma \mathrm{CH} H), 1.01(1 \mathrm{H}, \mathrm{m}, \operatorname{Arg} \beta \mathrm{CH} H),-0.44(1 \mathrm{H}, \mathrm{m}, \operatorname{Arg}$ $\beta \mathrm{CH} H$ ); Analytical RP-HPLC (5-60\% B in $20 \mathrm{~min}, \lambda=220 \mathrm{~nm})$ : $\mathrm{R}_{\mathrm{t}}$ : 13.5min; $\mathrm{MS}\left(\mathrm{ES}+\right.$ ) calcd for $\mathrm{C}_{31} \mathrm{H}_{45} \mathrm{~N}_{10} \mathrm{O}_{11}$ : 733.3269; found: $733.3282[\mathrm{M}+\mathrm{H}]^{+}$.

\section{$\operatorname{Arg}(\mathrm{MC}) \rightarrow \operatorname{Orn}(\mathrm{MC})(20)$}

Scale: $0.094 \mathrm{mmol}$. Yield: $11.1 \mathrm{mg}, 16 \% .{ }^{1} \mathrm{H}$ NMR $(600 \mathrm{MHz}$, $\left.\mathrm{D}_{2} \mathrm{O}\right): \delta 7.58-7.39(5 \mathrm{H}, \mathrm{m}, \mathrm{MePhe} 2 \times \delta \mathrm{CH}, 2 \times \varepsilon \mathrm{CH}, \zeta \mathrm{CH}), 5.25$ $(1 \mathrm{H}, \mathrm{dd}, J=11,3$, MePhe $\alpha \mathrm{CH}), 4.92(1 \mathrm{H}, \mathrm{dd}, J=12.5,2.5$, Asp $\alpha \mathrm{CH}), 4.68(1 \mathrm{H}, \mathrm{m}, \mathrm{Asp} \alpha \mathrm{CH}), 4.40-4.32$ (2H, m, Orn $\alpha \mathrm{CH}$, Ala $\alpha \mathrm{CH}), 3.34-3.12\left(3 \mathrm{H}, \mathrm{m}, \mathrm{MePhe} \mathrm{\beta CH}_{2}\right.$, Orn $\left.\delta \mathrm{CH} H\right), 3.01$ (3H, s, MePhe $\left.\mathrm{NCH}_{3}\right), 2.98-2.88$ (4H, m, Orn $\delta \mathrm{CH} H, A s p \beta \mathrm{CH}_{2}$, Asp $\beta \mathrm{CH} H,), 2.83\left(3 \mathrm{H}, \mathrm{s}, \mathrm{MeCbm} \mathrm{CH}_{3}\right), 2.69(1 \mathrm{H}, \mathrm{t}, J=13$, Asp $\beta \mathrm{CH} H), 1.50-1.41$ (4H, m, Ala $\beta_{\mathrm{C} H}$, Orn $\left.\gamma \mathrm{CH} H\right), 1.24-1.16$ $(2 \mathrm{H}, \mathrm{m}$, Orn $\gamma \mathrm{CH} H$, Orn $\beta \mathrm{CH} H),-0.25(1 \mathrm{H}, \mathrm{m}$, Orn $\beta \mathrm{CH} H) ;{ }^{13} \mathrm{C}$ NMR (100 MHz, $\left.\mathrm{D}_{2} \mathrm{O}\right): \delta 175.5,175.4,175.0,174.5,171.7,171.6$, 170.3, 161.5, 138.2, 130.4, 129.9, 128.2, 62.9, 51.0, 50.5, 50.1, 49.7, 40.0, 38.6, 35.8, 34.2, 30.3, 27.6, 27.2, 17.7; Analytical RP-HPLC $(5-60 \% \mathrm{~B}$ in $20 \mathrm{~min}, \lambda=220 \mathrm{~nm}): \mathrm{R}_{\mathrm{t}}: 12.2 \mathrm{~min}$; MS (ES+) calcd for $\mathrm{C}_{28} \mathrm{H}_{40} \mathrm{~N}_{7} \mathrm{O}_{10}: 634.2831$; found: $634.2831[\mathrm{M}+\mathrm{H}]^{+}$.

\section{$\operatorname{Arg}($ MC) $\rightarrow$ His (21)}

Scale: 0.094 mmol. Yield: $4.4 \mathrm{mg}, 7 \% .{ }^{1} \mathrm{H}$ NMR (400 MHz, $\left.\mathrm{D}_{2} \mathrm{O}\right)$ : $\delta 8.47(1 \mathrm{H}, \mathrm{s}$, His $\varepsilon \mathrm{CH}), 7.18-7.04(5 \mathrm{H}, \mathrm{m}, \mathrm{MePhe} 2 \times \delta \mathrm{CH}, 2 \times$ $\varepsilon \mathrm{CH}, \zeta \mathrm{CH}), 6.92(1 \mathrm{H}, \mathrm{s}, \mathrm{His} \delta \mathrm{CH}), 5.08(1 \mathrm{H}, \mathrm{m}, \mathrm{MePhe} \alpha \mathrm{CH})$,
$4.65(1 \mathrm{H}, \mathrm{m}, \mathrm{Asp} \alpha \mathrm{CH}), 4.50(1 \mathrm{H}, \mathrm{dd}, J=11,3.5$, His $\alpha \mathrm{CH}), 4.45$ $(1 \mathrm{H}, \mathrm{dd}, J=11.5,2.5$, Asp $\alpha \mathrm{CH}) 3.93(1 \mathrm{H}, \mathrm{q}, J=7.5$, Ala $\alpha \mathrm{CH})$, $3.08(1 \mathrm{H}, \mathrm{dd}, J=14,3$, MePhe $\beta \mathrm{CH} H), 2.98-2.90$ (2H, m, MePhe $\beta \mathrm{CH} H, \mathrm{His} \beta \mathrm{CH} H), 2.68(1 \mathrm{H}, \mathrm{dd}, J=13.5,3, \mathrm{Asp} \beta \mathrm{CH} H), 2.84$ $2.71\left(5 \mathrm{H}, \mathrm{m}\right.$, His $\beta \mathrm{CH} H$, Asp $\left.\beta \mathrm{CH} H, \mathrm{MeCbm} \mathrm{CH}_{3}\right), 2.42-2.35$ $(2 \mathrm{H}, \mathrm{m}, 2 \times \mathrm{Asp} \beta \mathrm{CH} H), 1.04\left(3 \mathrm{H}, \mathrm{d}, J=7.5\right.$, Ala $\left.\beta \mathrm{CH}_{3}\right) ;{ }^{13} \mathrm{C}$ NMR (100 MHz, $\left.\mathrm{D}_{2} \mathrm{O}\right): \delta 175.3,175.2,174.4,172.5,171.5,171.1$, $170.4,137.4,133.5,129.6,129.2,128.9,127.4,115.9,62.7,50.7$, 50.1, 49.6, 46.9, 37.7, 35.3, 33.4, 30.1, 24.8, 16.5; Analytical RP$\operatorname{HPLC}(5-60 \% \mathrm{~B}$ in $20 \mathrm{~min}, \lambda=220 \mathrm{~nm}): \mathrm{R}_{\mathrm{t}}: 11.4 \mathrm{~min}$; MS (ES+) calcd for $\mathrm{C}_{27} \mathrm{H}_{34} \mathrm{~N}_{7} \mathrm{O}_{9}$ : 600.2413; found $600.2394[\mathrm{M}+\mathrm{H}]^{+}$.

\section{MePhe $\rightarrow \operatorname{MeTyr}(B n)(22)$}

Scale: $0.075 \mathrm{mmol}$. Yield: $2.2 \mathrm{mg}, 3 \% .{ }^{1} \mathrm{H}$ NMR $(600 \mathrm{MHz}$, $\left.\mathrm{CD}_{3} \mathrm{CN}\right): \delta 7.41-7.29(5 \mathrm{H}, \mathrm{m}, 5 \times \mathrm{ArCH}), 7.11(2 \mathrm{H}, \mathrm{d}, J=8.5$, MeTyr, $2 \times \operatorname{ArCH}), 6.94(2 \mathrm{H}, \mathrm{d}, J=8.5$, MeTyr, $2 \times \mathrm{ArCH}), 5.03$ $\left(2 \mathrm{H}, \mathrm{s}, \mathrm{OCH}_{2} \mathrm{Ar}\right), 4.93(1 \mathrm{H}, \mathrm{m}, \mathrm{MeTyr} \alpha \mathrm{CH}), 4.62(1 \mathrm{H}, \mathrm{m}, \mathrm{Asp}$ $\alpha \mathrm{CH}), 4.42(1 \mathrm{H}, \mathrm{m}, \mathrm{Asp} \alpha \mathrm{CH}), 4.20-4.10(2 \mathrm{H}, \mathrm{m}, \mathrm{Arg} \alpha \mathrm{CH}$, Ala $\alpha \mathrm{CH}), 3.11-2.62\left(13 \mathrm{H}, \mathrm{m}, \mathrm{MeTyr} \beta \mathrm{CH}_{2}, \operatorname{Arg} \delta \mathrm{CH}_{2}, \mathrm{Asp} \beta \mathrm{CH}_{2}\right.$, Asp $\beta \mathrm{CH} H$, MeTyr $\left.\mathrm{NCH}_{3}, \mathrm{MeCbm} \mathrm{CH}_{3}\right), 2.42(1 \mathrm{H}, \mathrm{t}, J=13$, Asp $\beta \mathrm{CH} H), 1.43(1 \mathrm{H}, \mathrm{m}, \operatorname{Arg} \gamma \mathrm{CH} H), 1.24(3 \mathrm{H}, \mathrm{d}, J=7.5$, Ala $\left.\mathrm{CCH}_{3}\right), 1.18-1.04(2 \mathrm{H}, \mathrm{m}, \operatorname{Arg} \gamma \mathrm{CH} H, \operatorname{Arg} \beta \mathrm{CH} H),-0.22(1 \mathrm{H}$, $\mathrm{m}, \operatorname{Arg} \beta \mathrm{CH} H) ;{ }^{13} \mathrm{C} \mathrm{NMR}\left(100 \mathrm{MHz}, \mathrm{CD}_{3} \mathrm{CN}\right): \delta 175.5,174.3$, $171.1,158.5,137.9,131.8,131.1,129.5,129.0,128.6,116.2$, 70.7, 63.0, 51.1, 50.9, 50.1, 49.5, 41.5, 38.8, 36.1, 33.5, 30.2, 27.8, 26.7, 25.3, 17.8; Analytical RP-HPLC (5-60\% B in $20 \mathrm{~min}, \lambda=220 \mathrm{~nm})$ : $\mathrm{R}_{\mathrm{t}}: 17.2 \mathrm{~min}$; MS (ES+) calcd for $\mathrm{C}_{36} \mathrm{H}_{48} \mathrm{~N}_{9} \mathrm{O}_{11}$ : 782.3468; found $782.3476[\mathrm{M}+\mathrm{H}]^{+}$.

\section{MePhe $\rightarrow$ MeTyr (23)}

Scale: $0.075 \mathrm{mmol}$. Yield: $6.2 \mathrm{mg}, 10 \% .{ }^{1} \mathrm{H}$ NMR (400 MHz, $\mathrm{D}_{2} \mathrm{O}$ ): $\delta 7.35(2 \mathrm{H}, \mathrm{d}, J=8.5$, MeTyr $2 \times \operatorname{ArCH}), 7.09(2 \mathrm{H}, \mathrm{d}, J=8.5$, MeTyr $2 \times \operatorname{ArCH}), 5.31(1 \mathrm{H}, \mathrm{dd}, J=11.5,3$, MeTyr $\alpha \mathrm{CH}), 5.03$ $(1 \mathrm{H}, \mathrm{m}, \mathrm{Asp} \alpha \mathrm{CH}), 4.78(1 \mathrm{H}, \mathrm{dd}, J=12,2.5, \mathrm{Asp} \alpha \mathrm{CH}), 4.55(1 \mathrm{H}$, $\mathrm{m}, \operatorname{Arg} \alpha \mathrm{CH}), 4.43(1 \mathrm{H}, \mathrm{q}, J=7$, Ala $\alpha \mathrm{CH}), 3.35-3.02(10 \mathrm{H}, \mathrm{m}$, MeTyr $\left.\mathrm{\beta CH}_{2}, \operatorname{Arg} \delta \mathrm{CH}_{2}, \operatorname{Asp} \mathrm{\beta CH}_{2}, \operatorname{Asp} \beta \mathrm{CH} H, \mathrm{MeTyr} \mathrm{NCH}_{3}\right)$ $2.99(3 \mathrm{H}, \mathrm{s}, \mathrm{MeCbm} \mathrm{CH}), 2.76(1 \mathrm{H}, \mathrm{t}, J=13$, Asp $\beta \mathrm{CH} H), 1.73$ $(1 \mathrm{H}, \mathrm{m}, \operatorname{Arg} \gamma \mathrm{CH} H), 1.56\left(3 \mathrm{H}, \mathrm{d}, J=7\right.$, Ala $\left.\beta \mathrm{CH}_{3}\right), 1.47-1.38$ $(2 \mathrm{H}, \mathrm{m}, \operatorname{Arg} \gamma \mathrm{CH} H, \operatorname{Arg} \beta \mathrm{CH} H), 0.00(1 \mathrm{H}, \mathrm{m}, \operatorname{Arg} \beta \mathrm{CH} H) ;{ }^{13} \mathrm{C}$ NMR $\left(100 \mathrm{MHz}, \mathrm{D}_{2} \mathrm{O}\right): \delta 175.4,175.3,174.4,171.5,170.2,154.9$, 131.1, 129.1, 115.9 62.5, 50.6, 50.0, 49.6, 48.9, 40.8, 37.8, 35.1, 32.4, 29.8, 26.6, 26.0, 24.3, 16.8; Analytical RP-HPLC (5-60\% $\mathrm{B}$ in $20 \mathrm{~min}, \lambda=220 \mathrm{~nm}): \mathrm{R}_{\mathrm{t}}: 11.2 \mathrm{~min}$; $\mathrm{MS}(\mathrm{ES}+)$ calcd for $\mathrm{C}_{29} \mathrm{H}_{42} \mathrm{~N}_{9} \mathrm{O}_{11}: 692.2998$; found $692.3003[\mathrm{M}+\mathrm{H}]^{+}$.

\section{MePhe $\rightarrow$ Phe (24)}

Scale: $0.101 \mathrm{mmol}$. Yield: $6.3 \mathrm{mg}, 8 \% .{ }^{1} \mathrm{H}$ NMR (400 MHz, $\left.\mathrm{D}_{2} \mathrm{O}\right)$ : $\delta$ 7.24-7.05 (5H, m, Phe $2 \times \delta \mathrm{CH}, 2 \times \varepsilon \mathrm{CH}, \zeta \mathrm{CH}), 4.91(1 \mathrm{H}, \mathrm{dd}$, $J=12,4.5$, Asp $\alpha \mathrm{CH}) 4.59(1 \mathrm{H}, \mathrm{dd}, J=12.5,3.5$, Asp $\alpha \mathrm{C} H)$, $4.46(1 \mathrm{H}, \mathrm{dd}, J=14,4$, Phe $\alpha \mathrm{CH}), 4.17(1 \mathrm{H}, \mathrm{q}, J=7$, Ala $\alpha \mathrm{CH})$, $4.07(1 \mathrm{H}, \mathrm{m}, \operatorname{Arg} \alpha \mathrm{CH}), 3.30(1 \mathrm{H}, \mathrm{dd}, J=14,4$, Phe $\beta \mathrm{CH} H)$, 2.95-2.84 (4H, m, Asp $\left.\beta \mathrm{CH} H, A s p \beta C H H, A r g ~ \delta C_{2}\right), 2.77-2.57$ $(6 \mathrm{H}, \mathrm{m}$, Phe $\beta \mathrm{CH} H, 2 \times \mathrm{Asp} \beta \mathrm{CH} H, \mathrm{MeCbm} \mathrm{CH}), 1.39(2 \mathrm{H}$, $\left.\mathrm{m}, \operatorname{Arg} \gamma \mathrm{CH}_{2}\right), 1.23\left(3 \mathrm{H}, \mathrm{d}, J=7\right.$, Ala $\left.\beta \mathrm{CH}_{3}\right), 1.17(1 \mathrm{H}, \mathrm{m}, \mathrm{Arg}$ $\beta \mathrm{CH} H), 0.79(1 \mathrm{H}, \mathrm{m}, \operatorname{Arg} \beta \mathrm{CH} H) ;{ }^{13} \mathrm{C} \mathrm{NMR}\left(100 \mathrm{MHz}, \mathrm{D}_{2} \mathrm{O}\right): \delta$ 177.2, 174.8, 173.9, 173.8, 172.9, 171.6, 171.1, 137.5, 129.2, 128.8, $126.9,55.8,53.9,50.4,49.9,49.0,40.5,36.5,36.4,35.8,26.9,26.1$, 
22.9, 16.1; Analytical RP-HPLC (5-60\% B in $20 \mathrm{~min}, \lambda=220 \mathrm{~nm})$ : $\mathrm{R}_{\mathrm{t}}: 12.5 \mathrm{~min}$; MS (ES+) calcd for $\mathrm{C}_{28} \mathrm{H}_{40} \mathrm{~N}_{9} \mathrm{O}_{10}$ : 662.2893; found $662.2868[\mathrm{M}+\mathrm{H}]^{+}$.

\section{BAsp $\rightarrow$ BHse (25)}

Scale: 0.099 mmol. Yield: $8.4 \mathrm{mg}, 11 \% .{ }^{1} \mathrm{H}$ NMR (400 MHz, $\left.\mathrm{D}_{2} \mathrm{O}\right)$ : $\delta 7.78(1 \mathrm{H}, \mathrm{s}$, Hse OH), 7.26-7.08 (5H, m, MePhe $2 \times \delta \mathrm{CH}, 2 \times$ $\varepsilon \mathrm{CH}, \zeta \mathrm{CH}), 4.95(1 \mathrm{H}, \mathrm{dd}, J=12,2.5$, MePhe $\alpha \mathrm{CH}), 4.69(1 \mathrm{H}$, $\mathrm{m}$, Asp $\alpha \mathrm{CH}), 4.15-4.03(2 \mathrm{H}, \mathrm{m}$, Ala $\alpha \mathrm{CH}$, Arg $\alpha \mathrm{CH}), 3.96(1 \mathrm{H}$, $\mathrm{m}$, Hse $\alpha \mathrm{CH}), 3.66-3.55\left(2 \mathrm{H}, \mathrm{m}, \mathrm{Hse} \mathrm{CH}_{2} \mathrm{OH}\right), 3.28(1 \mathrm{H}, \mathrm{m}$, MePhe $\beta \mathrm{CH} H), 2.92-2.55\left(12 \mathrm{H}, \mathrm{m}\right.$, MePhe $\beta \mathrm{CH} H$, Asp $\beta_{\mathrm{C}} H_{2}$, Arg $\delta \mathrm{CH}_{2}, \operatorname{Asp} \beta \mathrm{CH} H$, MePhe $\left.\mathrm{NCH}_{3}, \mathrm{MeCbm} \mathrm{CH}_{3}\right), 2.39(1 \mathrm{H}$, $\mathrm{dd}, J=14,12$, Asp $\beta \mathrm{CH} H), 1.46(1 \mathrm{H}, \mathrm{m}, \mathrm{Arg} \gamma \mathrm{CH} H), 1.24-0.98$ (5H, m, Ala $\left.\mathrm{BCH}_{3}, \operatorname{Arg} \gamma \mathrm{CH} H, \operatorname{Arg} \beta \mathrm{CH} H\right),-0.28(1 \mathrm{H}, \mathrm{m}, \mathrm{Arg}$ $\beta \mathrm{CH} H) ;{ }^{13} \mathrm{C}$ NMR $\left(100 \mathrm{MHz}, \mathrm{D}_{2} \mathrm{O}\right): \delta 175.1,174.7,174.2,172.5$, $171.5,170.5,165.1,163.3,163.0,155.3,153.6,137.7,129.7,129.2$, $128.8,127.21,117.9,63.6,61.8,50.0,49.6,49.4,48.4,40.7,38.2$, 37.0, 34.2, 33.7, 30.9, 27.1, 26.1, 23.8, 16.8; Analytical RP-HPLC $(5-60 \% \mathrm{~B}$ in $20 \mathrm{~min}, \lambda=220 \mathrm{~nm}): \mathrm{R}_{\mathrm{t}}: 13.0 \mathrm{~min}$; MS (ES+) calcd for $\mathrm{C}_{29} \mathrm{H}_{44} \mathrm{~N}_{9} \mathrm{O}_{9}$ : 662.3257; found $662.3248[\mathrm{M}+\mathrm{H}]^{+}$.

\section{Enzymology}

Inhibition of $A f$ ChiB1 was determined using the fluorogenic substrate 4-methylumbelliferyl- $\beta$-D- $N, N^{\prime}$-diacetylchitobiose (Sigma). In a final volume of $50 \mu \mathrm{L}, 2 \mathrm{nM}$ of enzyme was incubated with $20 \mu \mathrm{M}$ substrate in McIlvain buffer $(100 \mathrm{mM}$ citric acid, $200 \mathrm{mM}$ sodium phosphate, $\mathrm{pH} 5.5$ ) containing $0.1 \mathrm{mg} / \mathrm{mL}$ $\mathrm{BSA}$, for $10 \mathrm{~min}$ at $37{ }^{\circ} \mathrm{C}$ in the presence of different inhibitor concentrations. After the addition of $25 \mu \mathrm{L}$ of $3 \mathrm{M}$ glycine- $\mathrm{NaOH}$, $\mathrm{pH} \mathrm{10.3,} \mathrm{the} \mathrm{fluorescence} \mathrm{of} \mathrm{the} \mathrm{liberated} \mathrm{4-methylumbelliferone}$ was quantified using a Flx 800 microtitreplate fluorescence reader (Bio-Tek Instruments Inc.), with excitation and emission wavelengths of $360 \mathrm{~nm}$ and $460 \mathrm{~nm}$, respectively, using $40 \mathrm{~mm}$ slits. Experiments were performed in triplicate. Production of 4-methylumbelliferone was linear with time for the incubation period used, and less than $10 \%$ of available substrate was hydrolysed.

\section{Acknowledgements}

This work was supported by Wellcome Trust project grant 074337 (to IME and DvA) and a BBSRC studentship (AN). DvA is supported by a Wellcome Trust Senior Research Fellowship and the EMBO Young Investigator Programme. We thank Dr T. Woodman for assistance with the NMR analyses.

\section{References}

1 (a) C. A. Munro and N. A. R. Gow, Med. Mycol., 2001, 39, 41-53; (b) H. Merzendorfer, J. Comp. Physiol. [B], 2006, 176, 1-15; (c) M. T. Harris, K. Lai, K. Arnold, H. F. Martinez, C. A. Specht and J. A. Fuhrman, Mol. Biochem. Parasitol., 2000, 111, 351-362.

2 J.-P. Latgé, Mol. Microbiol., 2007, 66, 279-290.

3 J. Saguez, F. Dubois, C. Vincent, J. -C. Laberche, B. S. Sangwan-Norreel and P. Giordanengo, Pest. Manag. Sci., 2006, 62, 1150-1154.

4 B. Tachu, S. Pillai, R. Lucius and T. Pogonka, Inf. Immun., 2008, 76, 221-228.

5 Y.-L. Tsai, R. E. Hayward, R. C. Langer, D. A. Fidock and J. M. Vinetz, Infect. Immun., 2001, 69, 4048-4054.

6 (a) G. H. Renkema, R. G. Boot, A. O. Muijsers, W. E. DonkerKoopman and J. M. F. G. Aerts, J. Biol. Chem., 1995, 270, 2198-2202; (b) R. G. Boot, G. H. Renkema, A. Strijland, A. J. van Zonneveld and J. M. F. G. Aerts, J. Biol. Chem., 1995, 270, 26252-26256.

7 R. G. Boot, E. F. C. Blommaart, E. Swart, K. Ghauharali-van der Vlugt, N. Bijl, C. Moe, A. Place and J. M. F. G. Aerts, J. Biol. Chem., 2001, 276, 6770-6778.

8 (a) M. G. Nair, L. J. Gallagher, M. D. Taylor, P. Loke, P. S. Coulson, R. A. Wilson, R. M. Maizels and J. E. Allen, Inf. Immun., 2005, 73, 385-394; (b) H. F. Bigg, R. Wait, A. D. Rowan and T. E. Cawston, J. Biol. Chem., 2006, 281, 21082-21095; (c) Z. ul-Haq, P. Dalal, N. N. Aronson and J. D. Madura, Biochem. Biophys. Res. Commun., 2007, 359, 221-226.

9 Z. Zhu, T. Zheng, R. J. Homer, Y.-K. Kim, N. Y. Chen, L. Cohn, Q. Hamid and J. A. Elias, Science, 2004, 304, 1678-1682.

10 C. Jacques, A. D. Recklies, A. Levy and F. Berenbaum, OsteoArthritis and Cartilage, 2007, 15, 138-146.

11 A. P. Bussink, M. van Eijk, G. H. Renkema, J. M. Aerts and R. G. Boot, Int. Rev. Cytol., 2006, 252, 71-128.

12 O. A. Andersen, M. J. Dixon, I. M. Eggleston and D. M. F. van Aalten, Nat. Prod. Rep., 2005, 22, 563-579.

13 S. Sakuda, A. Isogai, S. Matsumoto, A. Suzuki and K. Koseki, Tetrahedron Lett., 1986, 27, 2475-2478.

14 S. Sakuda, Y. Nishimoto, M. Ohi, M. Watanabe, S. Takayama, A. Isogai and Y. Yamada, Agric. Biol. Chem. Y., 1990, 54, 1333-1335.

15 S. Sakuda, "Studies on the chitinase inhibitors, allosamidins", in Chitin Enzymology, Vol. 2, (R. A. A. Muzzarelli, Ed.), Atec Edizione, Grottammare, Italy, 1990, pp. 203-212.

16 A. Berecibar, C. Grandjean and A. Siriwardena, Chem. Rev., 1999, 99, 779-844.

17 T. J. Donohoe and C. P. Rosa, Org. Lett., 2007, 9, 5509-5511.

18 N. Arai, K. Shiomi, Y. Iwai and S. Omura, J. Antibiot., 2000, 53, 609614.

19 N. Arai, K. Shiomi, Y. Yamaguchi, R. Masuma, Y. Iwai, R. Turberg, H. Kolbl and S. Omura, Chem. Pharm. Bull., 2000, 48, 14421446.

20 M. J. Dixon, O. A. Andersen, D. M. F. van Aalten and I. M. Eggleston, Bioorg. Med. Chem. Lett., 2005, 15, 4717-4721.

21 M. J. Dixon, O. A. Andersen, D. M. F. van Aalten and I. M. Eggleston, Eur. J. Org. Chem., 2006, 5002-5006.

22 (a) F. V. Rao, D. R. Houston, R. G. Boot, J. M. F. G. Aerts, M. Hodkinson, D. J. Adams, K. Shiomi, S. Omura and D. M. F. van Aalten, Chem. Biol., 2005, 12, 65-76; (b) O. A. Andersen, A. Nathubhai, M. J. Dixon, I. M. Eggleston and D. M. F. van Aalten, Chem. Biol., 2008, 15, 295-301.

23 K. Barlos, D. Gatos, J. Kallitsis, G. Papaphotiu, P. Sotiriu, Y. Wenqi and W. Schafer, Tetrahedron Lett., 1989, 30, 3943-3946.

24 B. W. Bycroft, W. C. Chan, S. R. Chhabra and N. D. Hone, J. Chem. Soc. Chem. Commun., 1993, 778-779.

25 M. Dessolin, M. -G. Guillerez, N. Thieriet, F. Guibé and A. Loffet, Tetrahedron Lett., 1995, 36, 5741-5744.

26 J. Coste, D. Le Nguyen and B. Castro, Tetrahedron Lett., 1990, 31, 205-208.

27 (a) M. Mergler and F. Dick, J. Peptide Sci., 2005, 11, 650-657; (b) Formation of aspartimides with $\beta$-Asp peptides: B. K. Handa and C. H. Hassall, J. Chem. Soc. Perkin Trans 1, 1976, 2014-2019.

28 When the synthesis was conducted via side-chain anchoring of Asp to $p$-alkoxybenzyl alcohol (Wang) resin (see J. Tulla-Puche and G. Barany, J. Org. Chem., 2004, 69, 4101-4107), treatment with DBU was found to result in complete elimination of cyclised material from the solid support.

29 Y. Nakayama and Y. Sanemitsu, J. Heterocycl. Chem., 1984, 21, 15531556.

30 C. Dini, N. Drochon, S. Feteneau, J. C. Guillot, C. Peixoto and J. Aszodi, Bioorg. Med. Chem. Lett., 2001, 11, 529-531.

31 E. Nicolas, E. Pedroso and E. Giralt, Tetrahedron Lett., 1989, 30, 497500 .

32 H. Naharissoa, V. Sarrade, M. Follet and B. Calas, Peptide Res., 1992, 5, 293-299.

33 R. A. Houghten, A. Beckman and J. M. Ostresh, Int. J. Pept. Protein Res., 1986, 27, 653-658.

34 We cannot yet exclude the possible formation of an intermediate aspartimide species undergoing regioselective opening to the desired product during isolation (see T. Geiger and S. Clarke, J. Biol. Chem., 1987, 262, 785-794).

35 E. Frérot, J. Coste, A. Pantaloni, M.-N. Dufour and P. Jouin, Tetrahedron, 1991, 47, 259-270. 